\title{
Use of Chromic Oxide-paper as an Indicator in Digestibility Studies with Pigs
}

\author{
Shu Furuya, Seiya Takahashi and Kenichi Kameoka \\ Department of Nutrition, National Institute of Animal Industry, \\ Tsukuba Norin-danchi P.O. Box 5, Ibaraki 305
}

(Received June 15, 1981)

\begin{abstract}
Three experiments were conducted to evaluate the use of chromic oxide-paper which contained approximately $42 \%$ of chromic oxide, on dry matter basis, as an indicator for the determination of the digestibility with pigs. The first and the second experiments compared the fecal recovery of chromic oxide-paper with that of chromic oxide-powder and of $4 \mathrm{~N}-\mathrm{HCl}$ insoluble ash, respectively. The third experiment studied the effects of collection time of feces on the digestibilities of dry matter, crude protein and energy using the chromic oxide-paper method. The fecal recovery of chromic oxide administered as paper was in the range of $99.2-101.5 \%$ and the digestibilities determined by this method were practically identical to those obtained by the total collection method. The fecal recoveries of the chromic oxide administered in the form of powder and of the $4 \mathrm{~N}$ $\mathrm{HCl}$ insoluble ash were 89.8 and $90.9 \%$, respectively, and digestibilities determined by those two indicator methods were significantly $(P<0.05)$ lower than those determined by the chromic oxide-paper and total collection methods. There was no significant difference $(P>0,05)$ in the digestibilities among the three collection periods (08:30-12:00, 12:00-15:30 and 15:30-08:30), indicating that the time for fecal collection is not critical. Jpn. J. Zootech. Sci., 53 (2): 99-104, 1982
\end{abstract}

In determining the digestibility of animal diets the total collection method and indicator methods are commonly used. Indicator methods have the advantage that they dispense with the quantitative measurement of feed intake and feces output. Although chromic oxide is most widely used as the indicator in pig digestion trials, some workers have been hesitant about accepting the chromic oxide method because of their inability to quantitatively recover $100 \%$ of the ingested indicator ${ }^{1,2)}$. Recovery rates of 75 to $87 \%$ of chromic oxide have been reported by MOORE $^{3)}$ and IsHIKAWA ${ }^{4}$.

Recently the use of $4 \mathrm{~N}-\mathrm{HCl}$ insoluble ash as an alternative to either chromic oxide or total collection have been evaluated in determining the digestibility in pigs ${ }^{1,2}$. However, the results obtained with the use of insoluble ash have not always been satisfactory. In some trials reported by MCCARTHY et al. ${ }^{1.2)}$ the digestibilities of energy or crude protein obtained by the insoluble ash method were lower than those obtained by total collection method, which suggested that some loss of insoluble ash might have occurred.

The objective of the present study was to evaluate the use of chromic oxide-paper developed for ruminants by CORBETT et $a l^{5}$ ), for the determination of the digestibility with pigs. 


\section{Materials and Methods}

Preparation of chromic oxide-paper and purification of chromic oxide-powder Chromic oxide-paper which was purchased from Nippon Kayaku Co. Ltd., Tokyo was shredded into pieces of about $1 \times 1 \mathrm{~mm}$, weighing about $0.2 \mathrm{mg}$. It contained approximately $42 \%$ chromic oxide on the dry matter basis. Chromic oxide-powder which was purchased commercially was purified as described by WhITBY and LANG ${ }^{6}$.

Feeding and preparation of feces samples Pigs were placed individually in the metabolism cages and were given $40 \mathrm{~g} / \mathrm{kg}$ body weight once a day at 08:30 of one of the experimental diets shown in Table 1. In each experiment, pigs were weighed at the beginning of the preliminary period and kept on a constant ration throughout the experimental period. Water was allowed ad libitum.

Feces were collected and were dried in a $60^{\circ} \mathrm{C}$ forced-air oven. Then, dried feces were allowed to equilibrate with air moisture, weighed, ground through a $1 \mathrm{~mm}$ screen in a laboratory mill and sampled for subsequent analyses.

Experiment 1 The administration of chromic oxide-paper was compared with the administration of chromic oxide-powder by examining daily fecal recovery of chromic oxide. Also, the digestibilities of dry matter and crude protein obtained by the

Table 1. Compositions of the experimental diets*

\begin{tabular}{lcc}
\hline \multicolumn{1}{c}{ Ingredient } & Diet 1 & Diet 2 \\
\hline Ground yellow corn & 30 & 22 \\
Milo & - & 22 \\
Barley meal & 23 & 22 \\
Wheat bran & 29.9 & 12 \\
Defatted rice bran & 5 & 4 \\
Soybean meal & 4 & 9 \\
White-fish meal & 3 & 4 \\
Alfalfa meal & 2.5 & 2.5 \\
Calcium carbonate & 0.6 & 0.7 \\
Dicalcium phosphate & 0.8 & 0.8 \\
NaCl & 0.45 & 0.5 \\
Vitamin and mineral mixtures** & 0.4 & 0.4 \\
L-lysine & 0.1 & - \\
DL-methionine & 0.15 & 0.1 \\
Composition (by analyses) & & \\
Dry matter (\%) & 87.7 & 86.8 \\
Crude protein (N $\times 6.25, \%)$ & 14.4 & 15.1 \\
Gross energy (kcal/g) & - & 3.87 \\
G & & \\
\hline
\end{tabular}

* $0.1 \%$ of chromic oxide-powder or chromic oxide-paper was added to each diet. **Providing (per $\mathrm{kg}$ diet): Vitamin A, 16,000 IU; Vitamin D, 3,200 IU; Vitamin E, $16 \mathrm{IU}$; thiamin, $3.2 \mathrm{mg}$; riboflavin, $16 \mathrm{mg}$; Vitamin $\mathrm{B} 6,3.2 \mathrm{mg}$; pantothenic acid, $7 \mathrm{mg}$; niacin, $3.2 \mathrm{mg}$; choline, $221 \mathrm{mg}$; folic acid, $1.6 \mathrm{mg}$; $\mathrm{Zn}, 48 \mathrm{mg}$; $\mathrm{Fe}, 40 \mathrm{mg} ; \mathrm{Mn}, 40 \mathrm{mg} ; \mathrm{Cu}, 8 \mathrm{mg} ; \mathrm{I}, 0.8 \mathrm{mg}$. 
two chromic oxide methods were compared with those obtained by the total collection method.

Six castrated male pigs of an average initial weight of $50 \mathrm{~kg}$ were given diet 1 for a 3-day preliminary period and were alloted to two treatments of three pigs each, during the following 10-day collection period, in which $0.1 \%$ of either chromic oxide-paper or chromic oxide-powder had been added to diet 1 . Feces were collected once daily.

Experiment 2 The fecal recovery of chromic oxide in the pig administered with the chromic oxide-paper was compared with that of the acid insoluble ash. Also, digestibilities of dry matter, crude protein and energy obtained by chromic oxidepaper, acid insoluble ash and total collection methods were compared.

Four castrated male pigs, weighing approximately $25 \mathrm{~kg}$ at the beginning of the experiment, were given diet 2 to which $0.1 \%$ chromic oxide-paper had been added. The experiment consisted of a 7-day preliminary period and a 10-day collection period. Feces were collected once a day.

Experiment 3 Three castrated male pigs, weighing approximately $25 \mathrm{~kg}$ at the beginning of the experiment were used to examine the effects of time of collection of the feces on digestibilities of dry matter, crude protein and energy by the determination with chromic oxide-paper method. They were given diet 2 to which $0.1 \%$ chromic oxide-paper had been added. After a 7-day preliminary feeding, feces were collected at 08:30, 12:00 and 15:30 daily throughout a 4-day collection period.

Chemical and statistical analyses Gross energy was measured for feed and feces by the use of a bomb calorimeter, and dry matter and nitrogen were determined by methods of $\mathrm{AOAC}^{7)}$. Chromic oxide and acid insoluble ash was determined by the method described by BRISSON ${ }^{8)}$ and by McCARTHy et al. ${ }^{1}$, respectively. The content of chromic oxide in diets containing chromic oxide-paper was obtained by calculation from the chromic oxide content of the paper. Date were statistically analyzed by a $t$-test.

\section{Results and Discussion}

Experiment $1 \quad$ Fig. 1 is a graphic representation of the daily fecal recovery of

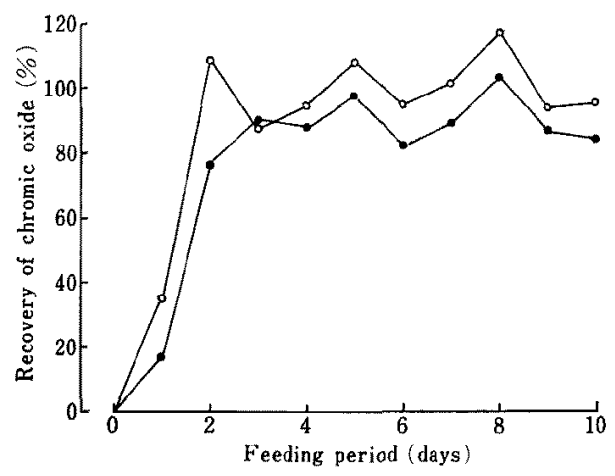

Fig. 1. Daily fecal recovery of chromic oxide in pig by days after initial feeding in Experiment 1 ( 0 , chromic oxide-paper; $\bullet$, chromic oxide-powder). 


\section{Furuya, Takahashi and Kameoka}

Table 2. Fecal recoveries of chromic oxide in pig administered with chromic oxide-powder or chromic oxide-paper and digestibilities of dry matter and crude protein determined by the methods of markers and total collection (Experiment 1, Diet 1$)^{*}$

\begin{tabular}{lccc}
\hline \multirow{2}{*}{ Method } & $\begin{array}{c}\text { Recovery }(\%) \\
\text { of chromic oxide }\end{array}$ & \begin{tabular}{c} 
Dry matter \\
\cline { 3 - 5 }
\end{tabular} & Crude protein \\
\hline Chromic oxide-powder & $89.8 \pm 1.3^{\mathrm{a}}$ & $74.4 \pm 0.2^{\mathrm{a}}$ & $72.9 \pm 0.8^{\mathrm{a}}$ \\
Chromic oxide-paper & $101.5 \pm 1.4^{\mathrm{b}}$ & $77.8 \pm 0.3^{\mathrm{b}}$ & $76.6 \pm 0.6^{\mathrm{b}}$ \\
Total collection & - & $77.2 \pm 0.2^{\mathrm{b}}$ & $75.9 \pm 0.5^{\mathrm{b}}$
\end{tabular}

*Values represent meantstandard error of the mean for three pigs. Recoveries of chromic oxide and digestibilities were calculated based on the analyses of an aliquot of the total feces voided in days 5-10. " different superscripts are significantly different $(P<0.05)$.

chromic oxide in the pig administered with chromic oxide-paper or chromic oxidepowder during a 10-day collection period. This indicates that recovery of chromic oxide in the administration with both paper and powder comes into equilibrium in less than 3 or 4 days after the initial feeding of the diet containing chromic oxide. In Table 2, the recovery of chromic oxide in the pig administered with chromic oxidepaper in the feces collected from 5 th to 10 th days was compared with that administered as chromic oxide-powder. The mean recovery of chromic oxide in the administration with chromic oxide-paper was achieved completely and therefore, the mean digestibilities of dry matter and crude protein agreed with the values obtained with the total collection method. While, in the case of the chromic oxide-powder, the mean digestibilities of dry matter and crude protein were significantly $(P<0.05)$ lower than those obtained with total collection method because of a low fecal recovery of chromic oxide. These results are consistent with the findings of other workers ${ }^{1,34}$.

Experiment 2 The mean recoveries of markers in the feces and the mean digestibilities of dry matter, crude protein and energy obtained by the three methods are presented in Table 3 . The mean recovery of acid insoluble ash in the feces was

Table 3. Fecal recoveries of markers and digestibilities of dry matter, crude protein and energy in pig determined by the methods of chromic oxide-paper, acid insoluble ash and total collection (Experiment 2, Diet 2)

\begin{tabular}{lccccc}
\hline \multirow{2}{*}{ Method } & $\begin{array}{c}\text { Recovery }(\%) \\
\text { of marker }\end{array}$ & Dry matter & Crude protein & Energy \\
\cline { 3 - 6 } & & Digestibility (\%) & \\
\hline Chromic oxide-paper & $99.2 \pm 0.9^{\mathrm{a}}$ & $79.6 \pm 0.2^{\mathrm{a}}$ & $79.3 \pm 0.7^{\mathrm{a}}$ & $78.8 \pm 0.3^{\mathrm{a}}$ \\
Acid insoluble ash & $90.0 \pm 1.3^{\mathrm{b}}$ & $77.5 \pm 0.3^{\mathrm{b}}$ & $77.2 \pm 0.6^{\mathrm{b}}$ & $76.6 \pm 0.3^{\mathrm{b}}$ \\
Total collection & - & $79.8 \pm 0.1^{\mathrm{a}}$ & $79.5 \pm 0.6^{\mathrm{a}}$ & $78.9 \pm 0.2^{\mathrm{a}}$ \\
\hline
\end{tabular}

*Values represent mean \pm standard error of the mean for four pigs. Recoveries of marker and digestibilities were calculated based on the analyses of an aliquot of the total feces voided in 10 day collection period. ${ }^{a}$ bValues in the same column with different superscripts are significantly different $(P<0.05)$. 
significantly $(\mathrm{P}<0.05)$ lower than that of chromic oxide in the pig administered with the chromic oxide-paper. The mean digestibilities of dry matter, crude protein and energy by acid insoluble ash method were significantly $(\mathrm{P}<0.05)$ lower than those obtained by chromic oxide-paper method or total collection method. McCARTHY et $a{ }^{1,2)}$, in the experiments using pigs, have reported higher digestibilities of crude protein and energy when they compared the results of total collection method with those of the acid insoluble ash method.

The fecal recovery of chromic oxide administered as chromic oxide-paper was almost achieved completely and therefore, no significant differences $(P>0.05)$ between the mean digestibilities of dry matter, crude protein and energy obtained by chromic oxide-paper method and those by total collection method were observed. These results are consistent with those in Experiment 1 with diet 1.

Experiment 3 Effects of collection time of feces on the digestibilities as determined by the chromic oxide-paper method were examined in Experiment 3 and the results were shown in Table 4. There was no significant difference $(\mathrm{P}>0.05)$ among the collection periods in the mean digestibilities of dry matter, crude protein and energy. These results indicate that the time of fecal collection is not critical for the components of the diet examined.

Table 4. Influence of the time of sampling the feces on the digestibilities of dry matter, crude protein and energy in pig determined by the chromic oxide-paper mehtod (Experiment 3 . Diet 2$)^{*}$

\begin{tabular}{llcl}
\hline \multirow{2}{*}{ Collection time } & \multicolumn{3}{c}{ Digestibility (\%) } \\
\cline { 2 - 4 } & Dry matter & Crude protein & Energy \\
\hline $08: 30-12: 00$ & $78.9 \pm 0.7$ & $75.5 \pm 1.6$ & $78.2 \pm 0.7$ \\
$12: 00-15: 30$ & $79.6 \pm 0.6$ & $76.9 \pm 0.7$ & $78.8 \pm 0.7$ \\
$15: 30-08: 30$ & $78.7 \pm 0.7$ & $76.6 \pm 1.1$ & $77.5 \pm 0.8$ \\
Total collection & $79.7 \pm 0.3$ & $77.1 \pm 0.9$ & $78.8 \pm 0.3$ \\
\hline
\end{tabular}

* Values represent mean \pm standard error of the mean for three pigs. Digestibilities were calculated based on the analyses of an aliquot of the total feces voided in each collection time in four day collection period. No significant differences $(P>0.05)$ were noted within comparison groupings.

The indicator used in the studies of digestibility should satisfy the following requirements; a) its fecal recovery is almost complete, and b) there should be little variation with time in the ratio of the fecal concentrations of indicator and nutrients studied.

Chromic oxide conventionally administered as the form of powder was, in the past, considered to be an accurate indicator. However, considerable doubt was cast on this assumption when workers such as $\mathrm{MOORE}^{3)}$ found that the fecal recovery of chromic oxide was not complete and therefore, the digestibilities determined by the chromic oxide method were lower than those obtained by the total collection method. 
Recently there has been the development of an alternative method of estimating the digestibilities in pig). This method involves the use of acid insoluble ash as indicator. However, the fecal recovery has not always been complete ${ }^{1,2)}$. Also, a low fecal recovery of acid insoluble ash was shown in the present study (Experiment 2).

The present experiments were conducted to evaluate the use of chromic oxidepaper as an indicator. The results indicated that the fecal recovery of chromic oxide in the administration with paper was almost achieved completely and that there was no significant difference among the digestibilities obtained with the three collection periods. Therefore, shredded chromic oxide-paper seems to satisfy the requirements mentioned above and to be an ideal indicator for the study of digestibility in pigs.

A disadvantage of chromic oxide-paper is that the amount added to diets must be weighed accurately for the calculation of chromic oxide content in diets. Direct measurement of chromic oxide content in diets would be unreliable because of variations occurring in sampling. Before weighing the paper it must be equilibrated with respect to moisture content in the environment.

\section{References}

1) McCarthy, J. F., F. X. Aherne and D. B. Okai. Can. J. Anim. Sci., 54: 107-109. 1974.

2) McCarthy, J.F., J. P. Bowland and F. X. Ahrene. Can. J. Arim. Sci., 57: 131-135. 1977.

3) Moore, J. H., Brit. J. Nutr., 11: 273-288. 1957.

4) Ishikawa, S., Agric. Biol. Chem., 30: 278-284. 1966.

5) Corbett, J. L., J. F. D. Greenhalgh, I. McDonald and E. Florence. Brit. J. Nutr., 14: 289299. 1960 .

6) Whitby, L. G. and D. Lang. J. Clin. Invest., 39: 854-863. 1960.

7) AOAC, Official Methods of Analysis 11 th ed. Association of Official Analytical Chemists, Washington, D. C. 1970.

8) Brisson, G. J., Can. J. Agr. Sci, 36:210-212. 1956.

\section{豚の消化試験における指標物質としての 酸化クロムペーパー}

\section{古谷 修・高橋正也・亀岡暄一}

農林水産省畜砅試験場，茨城県筑波農林研究団地 305

豚における消化舞測定の指標物質として，酸化クロム




酸化ク口ムペーパー休，酸化夕口ム空乾物換算で約 $42 \%$ 含有吉名市眅のもので，これを $1 \mathrm{~mm}$ 四方に切断し飼料 に0.1\%配合して用いた。実験 1 㧍よび2で酸化ク口

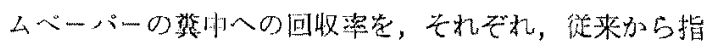
橴物質として用いられている酸化クロム粉木むよび酸不 溶性灰分の回収率之比較した，その結果，酸化タロムへ ーパーとして投与した酸化ク口ムの蕒中心の回收率は 99.2-101.5\%となり，それによって算出した消化率は全

日音会報，53(2)：99-104
罴採取法比上る值と大差なかった、しかしながら、粉末 として投与した酸化タロムおよび酸不溶性灰分の回収率 はそれぞれ，89.8および90.9\%となり，これら指標物

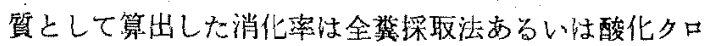
ムペーパー指標物質法による值よりも有意に（P<0.05）


12:00, 12:00-15:30 招よび 15:30-08:30 亿区分して採誉 し，各時刻における消化率を比較したが，乾物，粗蛋白 筫於よびェホルギーのいずれの消化率においても有意差 㹥認められなかった。

日离会報，53(2)：99-104, 1982 